\title{
"WEALTH OR LOVE, WHAT DOES A WOMAN WANT?" AN IRONIC LOOK AT THE MIDDLE CLASS NORMS IN CHARLOTTE BRONTE'S JANE EYRE
}

\author{
Afina Murtiningrum \\ Sultan Agung Islamic University \\ Semarang Indonesia \\ afina@unissula.ac.id
}

\begin{abstract}
Jane Eyre is a novel written in the early nineteenth century (1847). It depicts the English society of the upper, middle and lower class and their habits and attitudes towards life. The opening of the novel points to social class, wealth and marriage as its major theme. Throughout the novel, the relationship between social awareness of class and marriage, especially dealing with money or property are highlighted, the reason why society tends to consider about social class, money and property in finding a suitable partner to marry. This paper relies on the examples from the novel to show how nineteenth-century women imagined their marriage. In terms of women's social rights and roles, Charlotte Bronte tries to open readers' eyes to the idea that women's abilities should not be limited only to the sphere of the family. Bronte's novel does not only attack Victorian class structure but also the issue of gender.
\end{abstract}

Keywords: marriage, wealth, property, women's roles, gender

\section{INTRODUCTION}

"My bride is here," he said...."because my equal is here, and my likeness. Jane, will you marry me?" (Bronte 267)

This sentence from the last chapter of Jane Eyre can be seen as a Bronte's view of ideal marriage. Bronte argues that in a marriage, there should be equality between men and women; as she says "women feel just as men feel" (Bronte, 2006: 115). In term of marriage, this sentence also outlines the problem of the struggle of a middle-class woman to overcome the obstacles of traditional view of class difference, wealth and morality. Marriage in the nineteenth-century is not only discussing money or economic security, but it also deals with different social classes and property and how those things 
Murtiningrum, "Wealth Or Love, What Does A Woman Want?" An Ironic Look...

related to marriage. In Jane Eyre novel, the female protagonist tries to struggle to get married in convenience. Although it is very difficult, regarding their social status, property, family's connection and the conventional perception about marriage in the society, nevertheless finally the female protagonist can be together with her chosen partner in a marriage of equality. It seems that Jane Eyre as the author also uses the theme of marriage as a critique of the status of women in the nineteenth century. Since marriage was one of the dominant focuses of women at that time, this paper will analyze the representation of marriage in the nineteenth century, especially in relation to position of unmarried women of the middle class.

\section{DISCUSSION}

Unlike many contemporary societies, marrying for love for Victorian women, especially for middle-class women, is very uncommon. Marriage in the eighteenth and nineteenth centuries was not only a union of a man and a woman or between two families. Marriage at that time incorporates the issues of property and status of family as well (Teachman, 1997: 38). For upper-class families, it is very significant to marry someone within the same social class because it determines not only their social status and power but also the continuity of their wealth. This requirement motivates the upper-class family to find matches for their children even while their children are still babies. For middle-class families, marrying someone from higher social position will raise their social position and wealth. It is an obligation for middle-class women to marry someone from high social rank, especially to get financial security (Shapard, 2004: 645). As Martineau argues, "society forces women to languish in the legal and economic prison of the nineteenth-century marriage" (Frost, 1991: 265).

Thus, the ideal marriage based on love was not common. People in certain social classes did not think of love as a deciding factor in their marriage. Frost (1991) also argues that in the Victorian period, most middleclass women wanted to marry only for economic reasons, to get financial security (263). Similar to Frost, Newton (1978) also claims, "some single men, it would appear, have independent access to money, but all single women, or 
daughters, must marry for it" (28). From all the statements, it seems that money or financial security is a decisive factor in the consideration of a life partner.

Marriage of any kind at least brings an advantage for unmarried women, of gaining the status of wife. Women's position in society was not as equal as men: while men had their right to choose to marry or not to marry, women did not have these options, but rather they must marry for life (Newton, 1978: 28). As Frost (1991) states, marriage is "the only proper 'occupation' for a woman and a virtual life sentence to an inescapable economic and legal subjugation" (255).

By marrying someone, a woman could raise her social status in the society and avoid being a spinster. Most women in the nineteenth century were afraid of being unmarried women, and labeled with the derogatory 'spinster' or 'old maid'. An old maid or a spinster has been defined as "an older woman who never married. She passed the age of normal eligibility for marriage, which might occur by her late 20's and certainly would occur after she turned 30. Old maids were generally looked down upon and ridiculed, and were the subjects of variety of negative stereotypes" (Shapard, 2004: 407). Moreover, many essayists and books were written at that time to give awareness and warning about the issue of these unmarried women. An old maid or spinster had to depend on their family's financial to survive (Teachman, 1997: 87). However, Berend (2000) argues that being spinster is not always seen as a negative thing. Although society thought that became spinsterhood was "individual misfortune", but it can be seen as "a manifestation of protofeminist assertion of autonomy" (Berend, 2000: 2-3). In this context of the marriage market and fear of spinsterhood, the idealization of love-marriage becomes important both in society, and also in the narrative fiction produced within the society. A woman becomes a spinster not because she does not want to get married but she wants to find someone she really loves. She wants to marry based on love. Moreover, Berend also states that a woman prefer to be single and feel her independence to do something good rather than marry with someone she doesn't love, or in other word "The best, or none!" (Berend, 2000: 948). 
Murtiningrum, “Wealth Or Love, What Does A Woman Want?” An Ironic Look...

In relation to Jane Eyre novel, for Brontë Jane Eyre is more a protest novel than any other kinds. She writes this novel as a protest against the existing social conventions towards bourgeois patriarchal authority and the depiction of social class in which the upper class always behaves better than the middle-lower class. Furthermore, she points out the idea of women's rights and the notion of equality against the law of God and society mentioning that the women's role is only being subordinated to men. Brontë disputes the idea that a marriage is the only goal of a single woman in life, she expresses her feminine viewpoint by: "Such a woman now; trained from childhood to believe that for man, and for man alone, she must live, that marriage must be not only her highest, but her only aim on earth, as in it is comprised the whole of her destiny". Yet, Elizabeth Rigby sternly criticizes Brontë's protest against God and social convention of women's role by telling Jane Eyre as "the highest moral offence a novel writer can commit, that of making an unworthy character interesting in the eyes of the reader". Rigby mentions that Jane Eyre is a rebellion and unrestrained passion:

There is throughout it a murmuring against the comforts of the rich and against the privations of the poor, which...is a murmuring against God's appointment - there is a proud and perpetual assertion of the rights of man........is that pervading tone of ungodly discontent which is at once the most prominent and the most subtle evil which the law and the pulpit, which all civilized society in fact has a t the present day to contend with. We do not hesitate to say that the tone of mind and thought which has overthrown authority and violated every code human and divine abroad, and fostered Chartism and rebellion at home, as the same which has also written Jane Eyre (cited in Pell, 1977: 399).

From the citation above, it is clear that Charlotte Brontë's effort in undercutting and changing the image of women and their roles in the nineteenth century was uncommon.

The role of a single woman in nineteenth century is still primarily to fulfil two sacred things: to be a wife and mother and only be trained in doing her domestic duties. In her novel Jane Eyre Brontë tries to portray the traditional motif about a young girl who confronts difficulties in her development into maturity regarding the issues such as a woman's role, status, sexes, social classes, love and marriage in the community. Whilst 


\section{EduLite}

Journal of English Education, Literature, and Culture

marriage based on money or financial security is very common in the nineteen century considering the difficulties women had to face, in Jane Eyre Brontë tries to bring the idea that marriage is not merely based on a social contract (for material reasons), the love marriage is needed. Here Brontë points out the necessity about equality in marriage. She creates Jane as a woman who struggles against social conventions and the institution of marriage in the nineteenth century where women were always portrayed as the subordinates:

If at my individual convenience I might break them, what would be their worth? They have a worth - so I have always believed; and if I cannot believe it now, it is because I am insane: with my veins running fire, and my heart beating faster than I can count it throbs. Preconceived opinions, foregone determinations, are all I have at this hour to stand by: there I plant my foot (Bronte, 2006: 405).

The citation above shows clearly Jane's consciousness of her action against the social convention and the institution of marriage: she insists that the principles need to be changed.

Similar to her other novels, Bronte in Jane Eyre create her heroine as a tool to show the reader about the nineteenth century social patterns and setting. Brontë brings the upper and middle-lower classes along with their behaviour in her novels to criticize the society. Most of Brontë's concerns are related to women's proper sphere (Bjork, as cited in Handler \& Segal, 1995: 70). Furthermore, Brontë clearly describes about the miseries, thoughts and feelings of women living at that time throughout her novels. Women's lives were always depicted as agonies where there were many restrictions for them to do anything, no freedoms of choice whether to marry or not and only few job opportunities available for them to support their lives. Women were always considered as weak and not supposed to act as superior to men. In the character of Jane Eyre, Brontë brings a picture of a woman who is able to break the rule of women's passivity, decides anything by herself, strong, independent, able to support herself and be equal as man:

Women are supposed to be very calm generally: but women feel just as men feel; they need exercise for their faculties, and a field for their efforts as much as their brothers do; they suffer from too rigid a restraint, too absolute a stagnation, precisely as men would suffer...is thoughtless to condemn them, or laugh at them, if they seek to do more or learn more 
Murtiningrum, "Wealth Or Love, What Does A Woman Want?" An Ironic Look...

than custom has pronounced necessary for their sex (Bronte ${ }_{2}$ 132-133)

Here, the quote highlights how Jane Eyre comes against the traditional view of the nature of women, which are to be wife, mothers or mistress of a family. Moreover, she also describes the daily activities of women are only about joining parties, gossiping and having dinners in order to flirt and find suitable mates and marriage settlements. What makes Bronte different from the other authors is that Brontë criticizes the upper-middle class in a harsher style; she expresses a more daring protest, especially towards the aspect of femininity and female role. Feminist criticism considers Brontë as a writer who speaks for the oppressed women in her time. She rejects the social convention of women's role in the way women "ought to confine themselves to making puddings and knitting stockings, to playing on the piano and embroidering bags." (Bronte, 2006: 146).

As an object of the marriage market in order to enhance the status, Georgiana Reed in Jane Eyre novel can be seen as the best example. Her appearance in the novel is not only as a tool to criticize the issue of the marriage market women used to join to raise their status, but her appearance is also as a tool to criticize the upper class women (Bossche, 2005: 57). In Georgiana's case, she has to join the genteel marriage market not only to get financial security but also to raise her status. When John Reed's family fortune is scattered, Georgiana's decision in joining the genteel marriage market to find a wealthy man is a path a woman has to take to obtain security. Moreover, Georgiana also represents an unproductive aristocratic women who "when not lounging idly on the sofa, seeks only music, dancing and society" (Bronte, 2005: 235).

According to Sharmila Bhatt (as cited in Harish Trivedi, 1996 : 98), an unmarried middle-class woman who had enough education could became a governess or a writer to support herself or to supply her own necessities without relying on her family. A governess is defined as "a woman who taught in school, a woman who lived at home and travelled to her employer's house to teach (called a 'daily governess') or a woman who lived in her employer's home and who taught the children and served as a companion to them" (Peterson, 
8). Moreover, the number of governess increased when work opportunities opened for middle class women to work outside their home. Although opened but it was very limited, specific: unpaid duties within the home. Unfortunately, not only did they have to do unpaid duties within the home, but the large numbers of governesses also resulted in lower wages, unequal working conditions and in turn lowered their social position (Teachman, 1997: 95).

Being lower in their social position was also expressed strongly even further by a society that did not value female employment: "society has thought fit to assert that the woman who works for herself loses her social position" (Peterson, 1970: 9). Being a governess brings frustration and miseries. Not only is she treated as a subordinate by her master, she is also dependent upon the kindness of strangers. In one hand she is like an upper servant but on the other hand she is lower than the family. The frustration and miseries of the governesses in the eighteenth century can be seen in Mary Wollstonecraft writing on unmarried women, as cited in Teachman (1997: 95):

Painfully sensible of unkindness, she is alive to everything, and many sarcasms reach her, which were perhaps directed another way. She is alone, shout out from equality and confidence, and the concealed anxiety impairs her constitution; for she must wear a cheerful face, or be dismissed.

From all the citations above, it can be seen that working as a governess is under great pressure and the women at that time chose the job as governess because there are so few job opportunities open to them to work as governesses. The misery of the governess is a great interest to female novelists who address the working conditions, frustrations, and aspirations of women trapped in this role.

Dealing with the role of the governess, Rivers (as cited in Peterson, 1970: 24) explains that a governess has a dual position in the home family. In one side she should act as an actual mother doing all mothers' duties and on the other side she is only someone who paid to do what the mother wants to do for free, she is like a servant without say. Governess' appearance in the middle of the family home as a single woman is undeniable, her complicated relationship to men in the house is also a dilemma. Men could not treat them as female servant but they also could not give more attention to them. A 
Murtiningrum, "Wealth Or Love, What Does A Woman Want?" An Ironic Look...

governess tends to give a potential threat to the family where the governess works and it makes the family warns their sons not only to prevent the son on making relationship with the governess but also to avoid falling in love and married with the governess. Having a relationship with a governess will risk the family's status since the purpose of marriage is to extend the family's connection and to maintain the family's wealth, therefore a marriage between a son from the upper class and a governess from the middle-lower class is very restricted. The role described by Florence: "The governess is to have every one God's gift; she is to do that which the mother herself is incapable of doing; but our son must not degrade himself by marrying the governess (as cited in Peterson, 1970: 20). The only way to escape from the governess' misery entirely is marriage. The governesses in England seem to accept the idea of getting married as a permanent resolution for their status of incongruities.

In Jane Eyre, the misery of being unmarried middle-class woman and working as a governess at the same time is explored obviously. Brontë tells the reader how Jane Eyre as an unmarried woman has to live in a condition where women only had to be passive and subordinate to man while as a governess she has to live in an unusual and uncomfortable situation, in an isolated region accompanied with only a child and a housekeeper and lives without having access to others:

I climbed the three staircases, raised the trapdoor of the attic, and having reached the leads, looked out afar over sequestered field and hill, and along dim skyline- that then I longed for a power of vision which might overpass that limit; which might reach the busy world, towns, regions full of life I had heard of but never seen; that then I desired more of practical experience than I possessed; more of intercourse with my kind, of acquaintance with variety of character, than was here within my reach.

Who blames me? Many, no doubt: and I shall be discontented. I could not help it; the restlessness was in my nature; it agitated me to pain sometimes..._(Bronte, 2006: 178)

From this citation, the misery of being a governess is expressed through Jane's complaints about her condition surroundings: about the lonely her life is. Meanwhile, 'Who blames me' articulates her job as a governess; everybody knows and understands how bad working as a governess but there is nothing 
she can do, being a governess is the only job for her to make a living. Yet, Jane Eyre believes that her life and condition should be changed. She rejects the social convention that women are only supposed to make puddings, stockings, and playing: "It is vain to say human beings ought to be satisfied with: they must have action; they will make it if they cannot find it" (Bronte, 2006: 146).

The appearance of Mrs. Fairfax in Jane Eyre also emphasizes the importance of social class awareness in terms of marriage. Not only does Brontë present Mrs. Fairfax as a reminder of Jane's position as a governess who cannot be trusted to control her sexuality after she stands "pale, graved and amazed" observing Jane and Mr. Rochester declare their love, thus she warns Jane to "try and keep Mr. Rochester at a distance" (Bronte, 2006: 334), but she also comes as a reminder of social taboo about a marriage between two different classes, when she tells Jane that "gentleman in his station are not accustomed to marry their governess" (Bronte, 2006: 334). Here, Mrs. Fairfax does not only bring the issue of social class towards Jane's relationship to Mr. Rochester, but she also brings the issue of money to it. The notion of financial disposition comes out as a lesson for Jane who feels mortified because of her misfortune and makes her think twice about her relationship (Dupras, 1998: 397). Mrs. Fairfax comments to Jane: "Equality of position and fortune is often advisable in such cases" (Bronte, 2006: 293). This unequal position in money is one of the reasons why Jane refuses the marriage proposal from $\mathrm{Mr}$. Rochester. Barbara Weiss clearly states that Jane's depression is frequently happened to governess in nineteenth:

[T] here was dawning in the nineteenth century the reluctant knowledge that the institution of marriage was seriously flawed,,,[E]ven more particularly, the novels of Victorian women writers clearly suggest that the economic and social bases of marriage were being threatened by the changing values of the Victorian age; time and again, married union is envisioned as an insecure and tormenting state, susceptible to the same upheavals which are breaking down the traditional social values everywhere (Barbara Weiss as cited in Dupras, 1998: 398).

This remark points out the financial and social class constraints in the relationship between Jane and Mr. Rochester and for Jane these constraints are both exaggerated and warranted. 
Murtiningrum, "Wealth Or Love, What Does A Woman Want?" An Ironic Look...

Dealing with financial security and marriage, the novel Jane Eyre comes as a rebellion against the materialistic world in which marriage is only decided by money not by love and equality (Fraser as cited in Dupras, 1998: 407). Jane Eyre depicts the heroine's effort to get her economic independence. Jane Eyre in Jane Eyre novel feels that fortune also important in a marriage. She seeks her own fortune to get her independence by working as a teacher, thus there is an effort from the heroine to be independent: "--she seeks the independence that will free her from the tyranny of dependency she experiences at Gateshead, just as later she hopes for an "independency" when Rochester threatens to overwhelm her with his wealth" (Bronte, 2006: 268). Without a desire to join the marriage market, Jane only wants to be a selfmade woman who earns her living as a teacher (Bossche, 2005: 58). What she is doing at Thornfield, Lowood and Morton is merely because the job as a governess and a teacher provides her with economic independence. Therefore, Jane is not only longing for social inclusion and companion but also economic freedom (Bossche, 2005: 59).

Jane's decision to leave Mr. Rochester and Thornfield and discovers her new house and inheritance at Moor House proves how Jane is lacked of home and security, love and companionship but all of these sufferings do not stop her finding independence. Her effort to find independence again can be seen when she refuses John Rivers' marriage proposal. She rejects the marriage of convenience without love; even she argues that a marriage without love is unworthy by convincing him that they do not "love each other as man and wife should" (Bronte, 2006: 431). Here, Jane bravely rejects the false love from the man who will make her be another slave without freedom, therefore she leaves St. John: "but as his wife-at his side always, and always restrained, and always checked-forced to keep the fire of my nature continually low, to compel it to burn inwardly and never utter a cry, though the imprisoned flame consumed vital after vital-this would be unendurable" (Bronte, 2006: 429). Jane's leaving the Moor House is the part Brontë used Jane to come back to Rochester. Brontë shows how Jane has changed into a mature woman when she finally becomes brave to come back to Mr. Rochester and proposes Mr. Rochester to marry: "If you won’t let me live with you, I can build a house of | 
my own close up to your door.... will be your neighbour, your nurse, your housekeeper....I will be your companion...you shall not be left desolate, so long as I live" (Bronte, 2006: 556).

What is interesting in Jane Eyre is that Jane's decision to return to Rochester can be regarded as human responsibility; she knows that she has to return to Rochester after hearing a mysterious voice of Rochester needed a help : "seemed in me-not in th external world" (Bronte, 2006: 243). Jane has learnt to accept that Rochester cannot be blamed for his terrible marriage and she finally decides to come back to Mr. Rochester. Jane's returning to Rochester and wants to marry him when she knows that Bertha Mason is dead thus Rochester is legally and morally free to marry her without against the social and religious norms. Moreover, her decision to marry him is not only because of Rochester's transformation to be a man completely different from what he is before; achieving humanity he never has before, even he does try to safe Bertha Mason from the fire which proves that he is less arrogant and becomes more suited to Jane now, but also the recognition of Jane's equality. Mr. Rochester is dependent to Jane and helpless without Jane's help since he loses his right hand instead of his left. Here, Jane finally feels the equality with Rochester thus she says: "I love you better now, when I can really be useful to you, than I did in your state of proud independence, when you disdained every part but that of the giver and protector" (Bronte, 2006: 570). Still, Jane points out that equality in marriage is an important thing. She has gained her maturity and be able to overcome all the obstacles. Moreover, her searching of companion is ended by the ideal marriage based on love.

\section{CONCLUSION}

Jane Eyre by Charlotte Brontë comes as a protest against the social conventions restricting the position of women and their reliance on marriage for gaining social standing in the nineteenth century. The novel points out the idea of the possibility of love in marriage which was very uncommon at that time. Whilst the social system is very patriarchal, in which men are dominant and women are always portrayed as penniless or subordinates to men, marriage and opportunities for women are always seen as the only chance 
Murtiningrum, "Wealth Or Love, What Does A Woman Want?" An Ironic Look...

open to women for a secure future. All unmarried women in the nineteenth century are willing to get married without love as long as they get financial security and this is what Charlotte Brontë wants to explore in her fictions. The heroines in the novel rebels against the social convention of marriage by refusing to marry for convenience; she rejects the marriage proposals from men who offer financial security. By depicting society in a negative light in the novel, Brontë wants to show readers what is truly happening in particular English societies during the nineteenth century.

Marriage is a theme in Jane Eyre novel. Brontë in Jane Eyre depicts the negative effects of marriage under the issues of economic, social and patriarchal conventions. The issue of moral and religion are bound up with the theme of marriage and love. Jane as the major character is described as a device against the traditional role of women.

The interesting point from the novel is that the heroine in the novel comes from the middle-lower class who dreams of falling in love with rich men and marrying him. It seems that the heroine has been created in reaction to the social treatment of the poor girl in appearance and family's background and moreover against the notion of femininity which is always determined solely by beauty and good appearance. The heroine is explicitly described as less beautiful than other women in the novels but this lack of beauty does not limit her abilities to succeed in their lives: to fight for their freedom. In the end of the novel, the heroine and the hero are able to understand and respect others without considering social class and wealth.

\section{REFERENCES}

Berend, Zsuzsa. (2000). "The Best or None!" Spinsterhood in NineteenthCentury New England. Journal of Social History 33.4 (2000) 935-957.

Bossche, Chris R.Vanden (2005). "What Did Jane Eyre Do? Ideology, Agency, Class, and the Novel". NARRATIVE, Vol.13, No.1 (January 2005), pp. 46-62.

Bronte, Charlotte. (2006). Jane Eyre. Australia: Penguin Books.

Dupras, Joseph A. (1998). "Tying The Knot In The Economic Warp of Jane Eyre". Victorian Literature and Culture (1998), pp. 395-408. 
Frost, Cy. (1991). Autocracy and the matrix of power: issues of propriety and economics in the work of Mary Wollstonecraft, Jane Austen, and Harriet Martineau. Tulsa studies in women's literature, Vol. 10, No. 2 (Autumn, 1991), pp. 253-271.

Handler, Richard \& Segal, Daniel A. (1995). Hierarchies of choice: the social construction of rank in Jane Austen. American ethnologist, Vol. 12, No. 4 (Nov., 1985), pp. 691-706.

Newton, Judith Lowder. (1978). Pride and prejudice: power, fantasy and subversion in Jane Austen. Feminist studies, Vol. 4, No. 1 (Feb., 1978), pp. $27-42$

Pell, Nancy. (1977). "Resistance, Rebellion, and Marriage". Nineteenth-Century Fiction, Vol. 31, No. 4. (Mar., 1977), pp. 397-420

Peterson, M Jeanne. (1970). The Victorian governess: Status Incongruence in family and society. Victorian studies, Vol.14, No.1, September, 1970, pp.7-26.

Shapard, M. (2004). The annotated Pride and Prejudice. New York: A Division of Random House, Inc.

Teachman, Debra. (1997). Understanding Pride and Prejudice: A student casebook to issues, sources and historical documents. London: Greenwood Press.

Trivedi, Harish. (1996). Jane Austen: An anthology of recent criticism. Delhi: Pencraft International. 